\title{
PENERAPAN MODEL PEMBELAJARAN KOOPERATIF TIPE THINK PAIR SQUARE UNTUK MENINGKATKAN HASIL BELAJAR MATEMATIKA SISWA KELAS $X_{3}$ SMA NEGERI 5 PEKANBARU
}

\author{
Oleh : ${ }^{1}$ Titi Solfitri, ${ }^{2}$ Susda Heleni \\ ${ }^{1,2}$ Program Studi Pendidikan Matematika FKIP Universitas Riau, Pekanbaru \\ Email : ${ }^{1}$ tisolfitri@yahoo.com dan ${ }^{2}$ dewisusda@yahoo.com
}

\begin{abstract}
Abstrak:
Dalam melaksanakan proses pembelajaran di sekolah seorang guru hendaknya pandai memilih model pembelajaran yang sesuai dengan materi pembelajaran. Serta bisa memberikan waktu lebih banyak untuk siswa berpikir, merespon dan saling membantu serta dapat membantu siswa dalam memahami konsep materi pelajaran guna meningkatkan hasil belajar siswa. Salah satunya yaitu dengan model pembelajaran kooperatif tipe Think Pair Square. Model pembelajaran kooperatif tipe Think Pair Square memberikan kesempatan kepada siswa untuk bekerja di dalam kelompok heterogen baik dari segi kemampuan akademis, gender, latar belakang agama sosio-ekonomi dan etnik yang berbeda. Dengan penerapan model pembelajaran kooperatif Think Pair Square maka terjadi peningkatan hasil belajar matematika siswa kelas $X_{3}$ SMAN 5 Pekanbaru semester genap Tahun Pelajaran 2011/2012 pada materi pokok Trigonometri. Berdasarkan hasil penelitian dan pembahasan, dapat disimpulkan bahwa penerapan pembelajaran kooperatif tipe Think Pair Square dapat meningkatkan hasil belajar matematika siswa kelas $\mathrm{X}_{3}$ SMAN 5 Pekanbaru pada materi pokok Trigonometri semester genap tahun pelajaran 2011/2012. Hal itu dapat dibuktikan dari hasil observasi atau pengamatan secara langsung yang memperlihatkan bahwa terjadi peningkatan hasil belajar matematika siswa dari sebelumnya ke siklus pertama dan siklus kedua. Pada mula-mula jumlah siswa yang mencapai KKM berjumlah $6-10$ siswa, setelah mengikuti proses siklus pertama jumlah yang mencapai KKM berjumlah 15 siswa dan pada siklus kedua jumlah siswa yang mencapai KKM berjumlah 28 siswa dari total 32 siswa.
\end{abstract}

Kata kunci : Think Pair Square, Model Pembelajaran, Kooperatif

\section{Pendahuluan}

Matematika merupakan salah satu ilmu pengetahuan yang memegang peranan penting dalam pengembangan ilmu pengetahuan dan teknologi yaitu sebagai alat bantu, pembentuk pola pikir dan pembentuk sikap. Matematika membekali peserta didik untuk mempunyai kemampuan berpikir logis, analitis, sistematis, kritis, serta kemampuan bekerja sama. Matematika perlu diberikan kepada siswa guna membantu penataan nalar dan pembentukan kepribadian sehingga siswa diharapkan terampil menggunakan matematika dalam kehidupan. Oleh sebab itu, pelajaran matematika perlu diberikan kepada semua peserta didik dimulai dari sekolah dasar (Depdiknas, 2006). 
Hal ini sejalan dengan Kurikulum Tingkat Satuan Pendidikan (KTSP) yang menyatakan bahwa tujuan pendidikan nasional bidang pembelajaran matematika adalah agar peserta didik memiliki kemampuan; (1) Memahami konsep matematika, menjelaskan keterkaitan antar konsep dan mengaplikasikan konsep atau algoritma, secara luwes, akurat, efisien, dan tepat, dalam pemecahan masalah; (2) Menggunakan penalaran pada pola dan sifat, melakukan manipulasi matematika dalam membuat generalisasi, menyusun bukti, atau menjelaskan gagasan atau pernyataan matematika; (3) Memecahkan masalah yang meliputi kemampuan memahami masalah, merancang model matematika, menyelesaikan model dan menafsirkan solusi yang diproleh; (4) Mengkomunikasikan gagasan dengan simbol, tabel, diagram, atau media lain untuk memperjelas keadaan atau masalah; (5) Memiliki sikap menghargai kegunaan matematika dalam kehidupan, yaitu memiliki rasa ingin tahu, perhatian, dan minat dalam mempelajari matematika, serta sikap ulet dan percaya diri dalam pemecahan masalah (BSNP, 2006).

Djamarah dan Zain (2006) menyatakan bahwa kegiatan belajar mengajar ada dua hal yang ikut menentukan keberhasilan, yaitu pengaturan proses belajar mengajar dan pengajaran itu sendiri. Keduanya mempunyai hubungan saling ketergantungan satu sama lain, kemampuan mengatur proses pembelajaran yang baik akan menciptakan situasi yang memungkinkan anak untuk belajar, sehingga merupakan titik awal keberhasilan pembelajaran. Sardiman (2008) menambahkan bahwa proses belajar akan menghasilkan hasil belajar. Hasil yang diharapkan adalah hasil belajar matematika yang mencapai ketuntasan belajar. Siswa dikatakan tuntas hasil belajar matematika apabila nilai hasil belajar matematika siswa telah mencapai Krikteria Ketuntasan Minimum (KKM) yang telah ditetapkan sekolah (BSNP, 2006)

Dari hasil wawancara dengan guru matematika diperoleh hasil belajar matematika siswa SMA Negeri 5 Pekanbaru pada tahun ajaran 2011/2012, masih banyak siswa yang belum mencapai KKM yang ditetapkan oleh sekolah yaitu 75 . Hal ini dapat dilihat pada Tabel 1 
35 | al-Khwarizmi, Volume III, Edisi 1, Maret 2015, Hal. 33 - 50.

Tabel 1. Persentase Ketercapaian KKM Siswa Kelas X SMA Negeri 5 Pekanbaru Semester Ganjil Tahun Pelajaran 2011/2012

\begin{tabular}{|c|l|c|c|}
\hline No & \multicolumn{1}{|c|}{ Kompetensi Dasar } & $\begin{array}{c}\text { Jumlah siswa } \\
\text { yang Tuntas }\end{array}$ & $\begin{array}{c}\text { Persentase } \\
\text { Ketuntasan }\end{array}$ \\
\hline 1. & Sistem Persamaan Linear & 10 & $31,25 \%$ \\
2. & Pertidaksamaan Satu Variabel & 9 & $28,13 \%$ \\
3. & Logika Matematika & 6 & $18,75 \%$ \\
\hline
\end{tabular}

Sumber :Guru Matematika Kelas X SMA Negeri 5 Pekanbaru

Dari tabel 1 dapat dilihat bahwa hasil belajar matematika siswa masih rendah. Dikarenakan jika soal yang dimunculkan pada ulangan harian merupakan soal yang sering ditampilkan pada saat proses pembelajaran maka sebagian besar siswa bisa mengerjakannya. Tetapi jika soal yang diberikan sedikit dimodifikasi maka siswa mengalami kesulitan untuk mengerjakannya. Mengatasi rendahnya ketuntasan hasil belajar siswa ini, guru telah melakukan berbagai upaya seperti membentuk siswa belajar kelompok. Namun, usaha yang dilakukan tidak berhasil karena siswa dikelompokkan berdasarkan absen tanpa melihat kemampuan akademisnya, sehingga terlihat siswa yang berkemampuan tinggi yang terlihat aktif sedangkan siswa yang lainnya hanya diam saja dan menunggu jawaban teman dalam kelompoknya. Selain itu jika guru menjelaskan materi pembelajaran siswa hanya mengerti pada saat guru menjelaskan saja. Dikarenakan siswa telah terfokus untuk menghapal langkahlangkah pengerjaan soal sehingga jika soal yang diberikan berbeda maka siswa tidak bisa mengerjakannya.

Mengingat pentingnya penguasaan matematika oleh siswa maka guru perlu berupaya meningkatkan kualitas pembelajaran dengan melakukan beberapa usaha perbaikan, terutama dalam proses pembelajaran yang dilakukan oleh guru. Menanggapi permasalahan diatas yaitu kesenjangan antara kenyataan proses pembelajaran yang terjadi di kelas dengan proses pembelajaran yang diharapkan dalam Peraturan Menteri Pendidikan Nasional Republik Indonesia Nomor 41 Tahun 2007 tentang Standar Proses, maka pembelajaran matematika perlu suatu model pembelajaran yang sesuai untuk mengatasi masalah tersebut. Suatu model yang dapat mengoptimalkan partisipasi siswa dalam proses pembelajaran, memberikan waktu lebih banyak untuk siswa berpikir, merespon dan saling membantu serta dapat membantu siswa dalam memahami konsep materi pelajaran guna meningkatkan hasil belajar siswa. Salah satunya yaitu dengan model pembelajaran kooperatif tipe Think Pair Square. 
Model pembelajaran kooperatif tipe Think Pair Square memberikan kesempatan kepada siswa untuk bekerja di dalam kelompok heterogen baik dari segi kemampuan akademis, gender, latar belakang agama sosio-ekonomi dan etnik yang berbeda. Hal ini dimaksudkan agar setiap anggota kelompok mendapat kesempatan untuk saling belajar dan saling mendukung, meningkatkan relasi dan intereksi, serta memudahkan pengelolaan kelas (Lie, 2008).

Tahapan pelaksanaan pembelajaran kooperatif tipe Think Pair Square juga memberikan kesempatan kepada siswa untuk berfikir aktif dalam menentukan konsep materi yang dipelajari (think). Selanjutnya siswa bisa berbagi hasil pemikiran dengan pasangan dalam satu kelompoknya (pair) dan pada akhirnya dapat menyatukan ide antar pasangan dalam satu kelompok (square). Tahapan pembelajaran yang memiliki alur yang jelas serta terdistribusi dalam kelompok kecil akan membuat siswa lebih memahami materi karena lebih banyak waktu untuk berpikir, merespon, dan saling membantu. Diskusi akan berjalan efektif karena setiap siswa berpartisipasi aktif dalam kelompoknya. Berdasarkan uraian di atas, penulis akan melakukan penelitian dengan judul "Penerapan Model Pembelajaran Kooperatif Tipe Think Pair Square untuk Meningkatkan Hasil Belajar Matematika Siswa Kelas $X_{3}$ SMA Negeri 5 Pekanbaru tahun pelajaran 2011/2012 pada materi pokok Trigonometri”

\section{Tujuan}

Tujuan Penelitian ini adalah untuk meningkatkan hasil belajar matematika siswa kelas $X_{3}$ SMA Negeri 5 Pekanbaru semester genap tahun ajaran 2011/2012 pada materi pokok Trigonometri melalui penerapan model pembelajaran kooperatif tipe Think Pair Square

\section{Metode Penelitian}

\section{a) Tempat dan Waktu Penelitian}

Penelitian ini dilakukan di SMA Negeri 5 Pekanbaru pada semester genap tahun pelajaran 2011/2012.

\section{b) Jenis Penelitian}

Jenis penelitian ini adalah penelitian tindakan kelas yaitu suatu penelitian untuk memperbaiki proses belajar mengajar siswa yang bertujuan untuk memperbaiki mutu. Sedangkan tindakan 
37 | al-Khwarizmi, Volume III, Edisi 1, Maret 2015, Hal. 33 - 50.

kelas yang dilakukan dalam penelitian ini adalah penerapan pembelajaran kooperatif tipe Think Pair Square.

c) Subjek Penelitian

Subjek pada penelitian ini adalah siswa kelas $X_{3}$ SMA Negeri 5 Pekanbaru semester genap tahun pelajaran 2011/2012 sebanyak 32 orang siswa terdiri dari 13 orang siswa laki-laki dan 19 orang siswa perempuan dengan kemampuan akademis yang heterogen.

d) Rancangan Penelitian

Penelitian yang akan dilakukan oleh peneliti terdiri dari dua siklus. Kegiatan yang dilakukan pada setiap tahap adalah sebagai berikut:

1. Refleksi Awal: Pada tahap refleksi awal ini peneliti telah menentukan beberapa masalah yang dihadapi. Adapun masalah yang dihadapi tersebut guru kurang melibatkan siswa dalam proses pembelajaran, guru kurang memberikan kesempatan kepada siswa untuk mengungkapkan pengetahuan, pemikiran, dan pendapat dalam proses pembelajaran, serta guru belum dapat menciptakan interaksi sesama siswa dalam proses pembelajaran. Beberapa siswa kurang aktif dan cenderung menunggu penjelasan dari guru, dan guru jarang memberikan kesempatan kepada siswa untuk bekerja dalam kelompok. Berdasarkan masalah tersebut peneliti ingin menerapkan pembelajaran kooperatif tipe Think Pair Square dimana pada model pembelajaran ini memberikan kesempatan kepada siswa untuk bekerja sendiri serta bekerjasama dengan orang lain dan pada model pembelajaran ini bisa mengoptimalisasikan partisipasi siswa.

2. Perencanaan; Pada tahap perencanaan ini peneliti menyusun perangkat pembelajaran yang terdiri dari.

a) Mempersiapkan materi yang disajikan dalam pembelajaran.

b) Mempersiapkan alat dan sarana maupun perangkat pembelajaran yang terdiri dari silabus, Rencana Pelaksanaan Pembelajaran (RPP), Lembar Kerja Siswa (LKS) dan Lembar Pengamatan.

c) Menentukan skor dasar individu yang diperoleh dari hasil tes akhir sebelum tindakan dilakukan (sebelum penerapan pembelajaran kooperatif tipe think pair square). Skor dasar siswa pada siklus I diperoleh dari skor ulangan harian pada materi Logika Matematika. Skor dasar ini digunakan untuk menyusun kelompok kooperatif pada siklus I.

d) Membagi siswa dalam kelompok kooperatif tipe Think Pair Square terdiri dari 4 orang siswa yang dipilih secara 
heterogen. Kelompok dibentuk berdasarkan kelompok tinggi $25 \%$, kemampuan rendah $25 \%$, dan kemampuan sedang $50 \%$ (Trianto, 2009).

3. Pelaksanaan Tindakan; Pelaksanaan tindakan merupakan implementasi dari perencanaan. Kegiatan yang dilakukan oleh guru atau peneliti adalah dalam upaya memperbaiki atau meningkatkan mutu pembelajaran ke arah yang diinginkan. Pelaksanaan tindakan dilakukan pada proses pembelajaran secara terstruktur sesuai dengan Silabus, Rencana Pelaksanaan Pembelajaran (RPP), memberikan Lembar Kerja Siswa (LKS) dengan menerapkan pembelajaran kooperatif tipe Think Pair Square.

4. Pengamatan (Observasi); Dalam tahap ini yang bertindak sebagai pengamat utama adalah guru, dan tidak tertutup kemungkinan peneliti juga sekaligus mengamati jalannya tindakan. Pengamatan dilakukan terhadap aktivitas, interaksi dan kemajuan belajar siswa selama pembelajaran berlangsung. Pengamatan atau observasi dilakukan bersamaan dengan pelaksanaan tindakan. Pengamatan bertujuan untuk mengamati apakah ada hal-hal yang harus segera diperbaiki agar tindakan yang dilakukan mencapai tujuan yang diinginkan.

5. Refleksi; Refleksi dilakukan setelah tindakan berakhir yang merupakan perenungan bagi guru atau peneliti atas dampak dari proses pembelajaran yang dilakukan. Kegiatan refleksi akan menimbulkan pertanyaan yang bisa dijadikan sebagai acuan keberhasilan, misalnya apakah hasil belajar siswa sudah menunjukkan ketuntasan secara individual serta bagaimana respon siswa terhadap metode pembelajaran yang dilakukan. Hasil dari refleksi ini dapat dijadikan sebagai langkah untuk merencanakan tindakan baru pada pelaksanaan pembelajaran selanjutnya.

\section{e) Instrumen Penelitian}

Instrumen penelitian yang perlu dipersiapkan adalah: (1). Perangkat pembelajaran yang terdiri dari silabus, RPP, dan LKS; (2) Instrumen pengumpul data yang terdiri dari tes hasil belajar dan lembar pengamatan.

f) Teknik Analisis Data.

Data yang diperoleh baik melalui lembar pengamatan maupun tes hasil belajar matematika kemudian dianalisis sebagai panduan untuk menjawab hipotesis tindakan yang telah diajukan sebelumnya. Teknik analisis data yang digunakan yaitu analisis data statistik deskriptif. 
39 | al-Khwarizmi, Volume III, Edisi 1, Maret 2015, Hal. 33 - 50.

Sugiyono (2007) mengemukakan bahwa statistik deskriptif adalah statistik yang digunakan untuk menganalisis data dengan cara mendeskripsikan atau menggambarkan data yang telah terkumpul sebagaimana adanya tanpa bermaksud membuat kesimpulan yang berlaku untuk umum atau generalisasi.

1. Analisis Data Aktivitas dan Interaksi Belajar Siswa dan Guru

Analisis data tentang aktivitas siswa dan guru didasarkan dari hasil lembar pengamatan selama proses pembelajaran. Pada lembar pengamatan akan tampak kekurangan-kekurangan yang dilakukan oleh peneliti pada saat menerapkan pembelajaran. Kekurangankekurangan tersebut akan direfleksi oleh pengamat dan peneliti. Hasil dari refleksi ini dapat dijadikan sebagai langkah untuk memperbaiki kekurangan-kekurangan pada siklus pertama dan merencanakan tindakan baru pada siklus II.

2. Analisis Data hasil Belajar Matematika

a. Analisis Data Nilai Perkembangan Individu siswa dan penghargaan kelompok

Nilai perkembangan individu siswa pada siklus I diperoleh dari selisih nilai pada skor dasar dan nilai ulangan harian I. Nilai perkembangan individu pada siklus II diperoleh siswa dari selisih nilai ulangan harian I dan ulangan harian II. Penghargaan kelompok diperoleh dari nilai perkembangan kelompok yaitu ratarata nilai perkembangan yang diperoleh anggota kelompok.

b. Anilisis kesalahan siswa

Analisis kesalahan siswa dilakukan terhadap jawaban siswa dalam menyelesaikan soal ulangan harian I dan ulangan harian II. Analisis dilakukan dengan melihat langkah-langkah penyelesaian soal. Analisis ini berguna untuk melihat kesalahan yang sering dilakukan siswa. Kesalahan dikelompokkan menjadi 3 yaitu kesalahan konsep, prinsip, operasi atau prosedur. Menurut Edward Begle dalam Susda (2008), objek matematika adalah fakta, konsep, operasi dan prinsip yang semuanya adalah abstrak. Menurut Frederick H Bell mengklasifikasikan objek matematika sebagai objek langsung dan objek tidak langsung. Objek langsung dalam matematika terdiri dari fakta, konsep, operasi dan prinsip. Fakta matematika adalah suatu konvensi dalam matematika, suatu ide matematika yang disajikan baik dalam bentuk kata-kata maupun symbol atau lambang. Konsep menurut Frederick H Bell (1981) konsep matematika adalah suatu ide abstrak yang memungkinkan kita dapat mengelompokkan objek-objek atau kejadian itu merupakan contoh atau bukan contoh dari ide abstrak. Operasi merupakan gabungan antara fakta dengan konsep, sedangkan 
prinsip adalah suatu hubungan antara dua lebih objek-objek matematika

c. Analisis Ketercapaian Ketuntasan Indikator

Analisis data tentang ketercapaian kriteria ketuntasan indikator pada materi pokok Trigonometri dilakukan dengan melihat hasil belajar siswa secara individual yang diperoleh dari ulangan harian I dan ulangan harian II. Skor ulangan harian siswa untuk setiap indikator dihitung dengan menggunakan rumus berikut.

$$
\text { Skor }=\frac{\text { SP }}{\text { SM }} \times 100
$$

Dimana: $\mathrm{SP}=$ skor yang diperoleh siswa

$\mathrm{SM}=$ skor maksimal

Pada penelitian ini siswa dikatakan telah mencapai kriteria ketuntasan untuk setiap indikator apabila siswa mencapai skor $\geq$ 75 pada setiap indikator.

d. Analisis Keberhasilan Tindakan

Pada penelitian ini cara yang digunakan untuk menganalisis keberhasilan tindakan yaitu dengan analisis pada tabel distribusi frekuensi. Menurut Suyanto (1997), apabila skor hasil belajar siswa setelah tindakan lebih baik dari pada sebelum tindakan maka dapat dikatakan tindakan berhasil. Dengan kata lain, tindakan dikatakan berhasil jika hasil belajar siswa meningkat. Peningkatan hasil belajar siswa dapat dilihat dari perkembangan skor dasar, ulangan harian I dan ulangan harian II dianalisis setiap indikatornya untuk mengetahui ketercapaian KKM yang telah ditetepkan, kemudian dibandingkan dengan skor dasar.

\section{Hasil dan Pembahasan}

\section{A. Pelaksanaan Penelitian}

1. Tahap Pelaksanaan Proses Pembelajaran

Proses pembelajaran dilaksanakan dua kali dalam satu minggu dengan dua jam pelajaran setiap pertemuan. Pelaksanaan proses pembelajaran pada penelitian ini menggunakan dua siklus yang terdiri dari delapan pertemuan dengan rincian enam kali pertemuan untuk proses pembelajaran dan dua kali pertemuan untuk mengadakan tes yaitu ulangan harian I dan ulangan harian II.

a. Pelaksanaan Pembelajaran Siklus I

Setelah tiga kali pertemuan, guru melaksanakan ulangan harian I dengan memberikan tes hasil belajar pada sub pokok 
41 | al-Khwarizmi, Volume III, Edisi 1, Maret 2015, Hal. 33 - 50.

aturan sinus dan cosinus. Tes dilaksanakan selama 90 menit, soal terdiri dari 4 butir sesuai dengan indikator yang telah disediakan oleh guru . Pada menit ke 60 ada dua orang siswa yang menyatakan telah selesai mengerjakan soal yang diberikan. Guru meminta siswa tersebut untuk memeriksa kembali pekerjaannya. Guru memberikan peringatan kepada beberapa siswa yang berusaha menyalin pekerjaan temannya. Guru menengaskan kepada siswa untuk mengerjakan soal ulangan masing-masing. Setelah waktu yang ditentukan habis, seluruh siswa mengumpulkan jawabannya.

\section{b. Refleksi Siklus Pertama}

Berdasarkan lembar pengamatan, selama melakukan tindakan sebanyak tiga kali pertemuan terdapat beberapa kelemahankelemahan yang dilakukan oleh guru dan siswa. Kekurangankekurangan tersebut antara lain:

1) Guru belum mampu mengaktifkan semua siswa pada saat kegiatan awal pembelajaran dan pada saat membuat kesimpulan.

2) Guru kurang efisien dalam mengorganisasikan siswa dalam kelompok. Hal ini terlihat pada saat fase think. Guru meminta siswa duduk membentuk kelompok berempat. Walaupun kursi antar siswa sudah diberi jarak, namun kondisi ini membuat siswa memiliki kesempatan untuk menyalin jawaban temannya. Beberapa siswa juga belum serius dalam mengerjakan LKS pada saat think.

3) Pada fase pair, ada siswa yang hanya menyalin pekerjaan temannnya tanpa berdiskusi, ada juga siswa yang tetap mengerjakannya secara individu.

4) Pada fase square, masih ada kelompok yang belum berdiskusi. Anggota kelompok tersebut masih ada yang bekerja secara individu, ada pula yang tidak terlibat diskusi.

5) Guru kurang efektif dalam menggunakan waktu sehingga ada beberapa poin dari RPP yang tidak terlaksana.

Berdasarkan refleksi siklus I, peneliti menyusun rencana perbaikan sebagai berikut:

1) Berusaha mengaktifkan semua siswa dalam proses pembelajaran dengan memberikan motivasi berupa tambahan nilai bagi siswa yang aktif. Upaya lain yang dilakukan adalah jika siswa yang bersedia menjawab pertanyaan yang diajukan guru telah sering mengajukan diri, maka guru yang akan menunjuk siswa lain untuk menjawabnya. 
2) Pada saat fase think, siswa tidak diorganisasikan dalam bentuk kelompok. Siswa duduk secara individu seperti pada saat kegiatan awal pembelajaran. Setiap kursi siswa diberi jarak dengan kursi disebelahnya. Hanya saja, siswa dikondisikan agar duduk besebelahan dengan pasangannya sehingga pada saat fase pair, siswa dapat menggeser kursi mendekati pasangannya. Demikian pula pada fase pair, setiap pasangan siswa hanya membalikkan kursi ke belakang untuk membentuk kelompok berempat. Guru juga memberikan arahan kepada siswa tentang pentingnya mengerjakan LKS secara individu. Arahan yang diberikan berupa penjelasan bahwa fase think akan meningkatkan pemahaman siswa terhadap materi yang dipelajari.

3) Memberikan arahan pada siswa untuk berdiskusi pada fase pair. Arahan yang diberikan berupa penjelasan tentang pentingnya bekerja sama dengan pasangan untuk memahami materi yang terdapat dalam LKS. Guru juga memberikan motivasi pada siswa agar bersedia berdiskusi dengan pasangan. Motivasi diberikan dengan mengatakan pada siswa bahwa pada saat presentasi, guru yang akan memilih siswa secara acak untuk mempresentasikan LKS. Jika siswa tersebut dapat mempresentasikan LKS dengan baik, maka seluruh anggota dikelompoknya juga akan mendapat poin keaktifan.

\section{c. Pelaksanaan Pembelajaran Siklus Kedua}

Setelah tiga kali pertemuan, guru melaksanakan ulangan harian II dengan memberikan tes hasil belajar pada sub pokok bahasan luas segitiga. Tes dilaksanakan selama 90 menit. Soal terdiri atas 4 soal sesuai dengan indikator yang disediakan oleh guru. Pada menit ke 30, sudah ada tiga siswa yang menyatakan bahwa pekerjaannya telah selesai. Guru meminta siswa tersebut untuk memeriksa kembali jawabannya. Setelah waktu yang ditentukan selesai, guru meminta semua siswa untuk mengumpulkan jawaban.

\section{d. Refleksi Siklus Kedua}

Pelaksanaan siklus kedua lebih baik jika dibandingkan dengan siklus pertama. Siswa sudah mengerti dan terbiasa dengan langkah pembelajaran yang digunakan sehingga waktu yang digunakan lebih efektif. Siswa sudah aktif dalam proses pembelajaran dan dapat bekerja sama dengan pasangan. Siswa juga sudah aktif dalam diskusi antar pasangan dalam kelompok. Aktivitas guru juga sudah sesuai dengan rencana pelaksanaan pembelajaran. Kekurangankekurangan pada siklus pertama sudah diperbaiki pada siklus 
43 | al-Khwarizmi, Volume III, Edisi 1, Maret 2015, Hal. 33 - 50.

kedua. Untuk siklus kedua ini, guru tidak lagi melakukan perencanaan untuk siklus berikutnya karena penelitian ini hanya dilaksanakan sebanyak dua siklus.

B. Analisis Hasil Penelitian

a. Analisis Data Hasil Pengamatan

Kesesuaian antara langkah-langkah penerapan pembelajaran kooperatif tipe think pair square yang direncanakan pada pelaksanaan tindakan dalam proses pembelajaran dapat dilihat dari lembar pengamatan setiap pertemuan. Kemudian data yang diperoleh melalui lembar pengamatan tersebut dianalisis.

Pada pertemuan pertama, terdapat beberapa kekurangan dalam pelaksanaan tindakan yang dilakukan oleh guru. Aktivitas guru tidak seutuhnya sesuai dengan yang direncanakan. Guru terlalu terburu-buru dalam menyampaikan motivasi kepada siswa sehingga siswa belum bersemangat dalam mengikuti pelajaran. Pada saat apersepsi, guru belum melibatkan siswa secara aktif. Guru juga belum bisa mengorganisasikan siswa dengan tertib. Siswa lamban dalam pembentukan kelompok. Sebagian siswa menggunakan kesempatan ini untuk bergurau dengan temantemannya. Pada saat membimbing kelompok bekerja dan belajar, guru cukup kewalahan karena banyak siswa yang masing bingung cara mengerjakan LKS. yang tidak terlaksana adalah penghargaan kelompok dan membimbing siswa membuat kesimpulan. Tidak terlaksana karena siswa masih belum terbiasa dengan model pembelajaran yang dilaksanakan. Sehingga siswa masih ragu dalam pembentukan kelompok berpasangan dan kelompok berempat. Siswa masih lamban dalam berpindah dari individu ke berpasangan dan dari berpasangan ke berempat. Hal ini menyebabkan waktu yang seharusnya digunakan untuk memberikan penghargaan dan membimbing kesimpulan digunakan untuk diskusi kelompok dan presentasi.

Aktivitas siswa pada pertemuan pertama belum sesuai dengan perencanaan. Siswa masih kurang memberikan respon atas pertanyaan-pertanyaan yang diajukan guru pada saat apersepsi. Pada saat fase think, masih ada siswa yang berusaha menyalin pekerjaan teman dan beberapa siswa yang enggan mengerjakan LKS. Pada saat fase pair, beberapa pasangan siswa tetap mengerjakan LKS secara individu. Demikian pula pada fase square, ada beberapa kelompok yang belum melaksanakan diskusi dengan baik. Siswa juga belum mampu melakukan presentasi dengan baik. 
Guru merefleksi kesalahan-kesalahan yang dilakukan pada pertemuan pertama untuk diperbaiki pada pertemuan kedua. Refleksi ini membuat pertemuan kedua menjadi lebih baik dari pada pertemuan pertama.

b. Analisis Data Hasil Belajar

1) Analisis Ketercapaian KKM Indikator

Ketuntasan hasil belajar matematika siswa untuk setiap indikator dianalisis secara individu. Siswa dikatakan mencapai KKM indikator jika memperoleh nilai lebih atau sama dengan KKM setiap indikator yang telah ditetapkan. Berdasarkan lampiran $\mathrm{H}_{3}$ dapat dihitung persentase ketercapaian KKM setiap indikator pada siklus I. Persentase ketercapaian KKM pada siklus I dapat dilihat pada tabel 3

Tabel 6. Persentase Ketercapaian Indikator pada Ulangan Harian I

\begin{tabular}{|c|l|c|c|}
\hline No. & \multicolumn{1}{|c|}{ Indikator Pembelajaran } & $\begin{array}{c}\text { Jumlah Siswa yang } \\
\text { Mencapai KKM }\end{array}$ & $\begin{array}{c}\text { Persentase } \\
(\%)\end{array}$ \\
\hline 1 & $\begin{array}{l}\text { Menggunakan aturan sinus untuk } \\
\text { menentukan unsur suatu segitiga apabila } \\
\text { unsur lain diketahui. }\end{array}$ & 23 & $71,875 \%$ \\
\hline 2 & $\begin{array}{l}\text { Menentukan unsur-unsur suatu segitiga } \\
\text { apabila unsur lain diketahui dengan } \\
\text { menggunakan aturan sinus }\end{array}$ & 12 & $37,5 \%$ \\
\hline 3 & $\begin{array}{l}\text { Menentukan panjang sisi suatu segitiga } \\
\text { apabila panjang dua sisi yang lain dan } \\
\text { besar sudut yang diapit oleh kedua sisi } \\
\text { itu diketahui }\end{array}$ & 20 & $53,313 \%$ \\
\hline 4 & $\begin{array}{l}\text { Menentukan besar sudut suatu segitiga } \\
\text { apabila panjang sisi-sisinya diketahui }\end{array}$ & 14 & $43,75 \%$ \\
\hline
\end{tabular}

Sumber : Data olahan

Kesalahan-kesalahan yang dilakukan oleh siswa dalam mengerjakan soal UH 1 dapat dilihat pada gambar berikut :

Indikator 1 : Menggunakan aturan sinus untuk menentukan unsur suatu segitiga apabila unsur lain diketahui.



Dari gambar tersebut dapat dilihat bahwa siswa melakukan kesalahan dalam menghitung nilai sinus $125^{\circ}$ dalam menggunakan kalkulator. Hal ini mengakibatkan siswa salah dalam menghitung panjang sisi $c$. 
45 | al-Khwarizmi, Volume III, Edisi 1, Maret 2015, Hal. 33 - 50.

Indikator 2 : Menentukan unsur-unsur suatu segitiga apabila unsur lain diketahui dengan menggunakan aturan sinus.

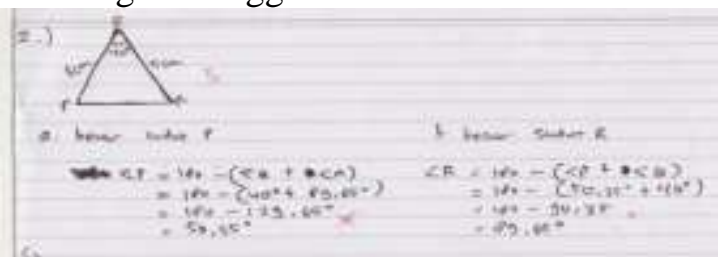

Dari gamber tersebut terlihat bahwa siswa melakukan kesalahan dalam mengkontruksi gambar. Hal ini menyebabkan siswa salah dalam menentukan besar sudut $\mathrm{P}$ dan sudut $\mathrm{R}$.

Indikator 3. Menentukan panjang sisi suatu segitiga apabila panjang dua sisi yang lain dan besar sudut yang diapit oleh kedua sisi itu diketahui.

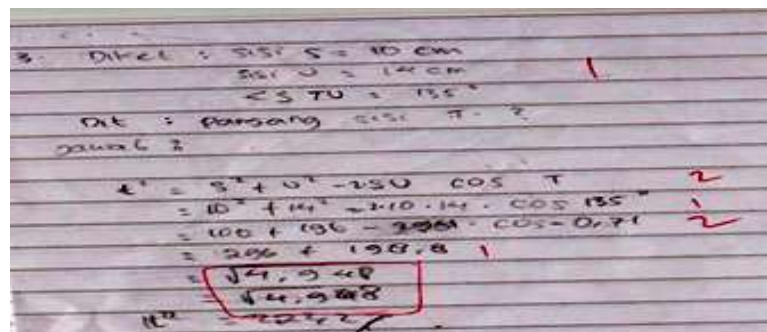

Berdasarkan gambar tersebut terlihat bahwa siswa melakukan kesalahan dalam melakukan operasi penjumlahan. Hal ini mengakibatkan siswa salah dalam menghitung panjang sisi $t$.

Indikator 4 : Menentukan besar sudut suatu segitiga apabila panjang sisi-sisinya diketahui

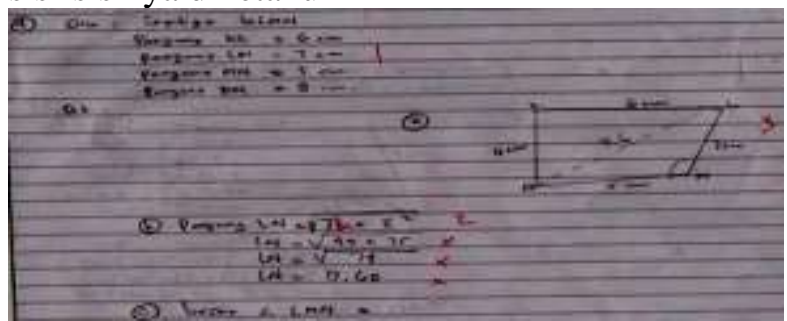

Terlihat dari gambar tersebut bahwa siswa melakukan kesalahan dalam menghitung panjang garis LN. Siswa tidak mengetahui sisi mana yang akan dimasukkan dalam dalil Pthagoras untuk menghitung panjang garis LN. Hal ini menyebabkan siswa salah dalam menentukan panjang garis LN. 
Penerapan Model Pembelajaran ...| 46

Tabel 7. Persentase Ketercapaian KKM indikator pada Ulangan Harian II

\begin{tabular}{|c|c|c|c|}
\hline $\begin{array}{c}\mathrm{N} \\
\mathrm{O}\end{array}$ & \multicolumn{1}{|c|}{ Indikator Pembelajaran } & $\begin{array}{c}\text { Jumlah Siswa } \\
\text { yang Mencapai } \\
\text { KKM }\end{array}$ & $\%$ \\
\hline 1 & $\begin{array}{l}\text { Menentukan luas segitiga apabila panjang dua } \\
\text { sisi dan besar sudut yang diapit oleh kedua sisi } \\
\text { diketahui. }\end{array}$ & 30 & 93,75 \\
\hline 2 & $\begin{array}{l}\text { Menentukan luas segitiga apabila panjang dua } \\
\text { sisi dan besar sudut dihadapan sisi diketahui }\end{array}$ & 23 & 71,88 \\
\hline 3 & $\begin{array}{l}\text { Menentukan luas segitiga apabila besar dua } \\
\text { sudut dan panjang satu sisi diketahui }\end{array}$ & 29 & 100 \\
\hline 4 & $\begin{array}{l}\text { Menentukan luas segitiga apabila panjang } \\
\text { ketiga sisinya diketahui }\end{array}$ & 32 & \\
\hline
\end{tabular}

Sumber : Data Olahan

Berdasarkan tabel 7 dapat dilihat bahwa ketercapaian KKM terendah terjadi pada indikator 2 yaitu $71,88 \%$ atau 23 siswa. Artinya, 9 siswa lain belum mencapai KKM. Kesalahan-kesalahan yang kebanyakan dilakukan oleh siswa dapat terlihat pada gambar berikut :

Indikator 1 : Menentukan luas segitiga apabila panjang dua sisi dan besar sudut yang diapit oleh kedua sisi diketahui.



Terlihat dari gambar tersebur bahwa siswa tidak mengetahui rumus untuk mencari luas dua buah segitiga untuk menghitung luas jajargenjang. Hal ini mengakibatkan peserta didik tidak bisa menjawab pertanyaan dengan benar.

Indikator 2 : Menentukan luas segitiga apabila panjang dua sisi dan besar sudut dihadapan sisi diketahui

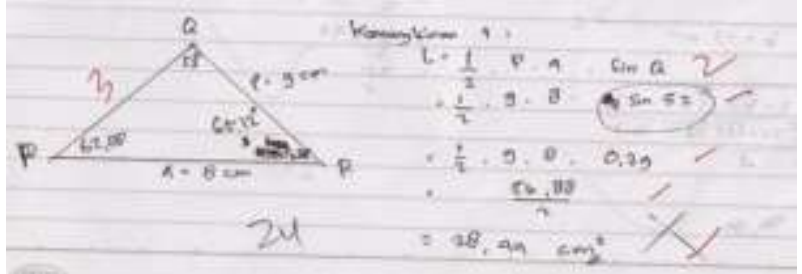

Berdasarkan gambar tersebur terlihat bahwa siswa kurang paham dalam memasukan panjang sisi yang mana untuk mencari luas segitiga apabila dua sisi dan satu sudut diketahui. Hal ini mengakibatkan peserta didik salah dalam mencari luas segitiga PQR dengan benar 
47 | al-Khwarizmi, Volume III, Edisi 1, Maret 2015, Hal. 33 - 50.

Indikator 3 : Menentukan luas segitiga apabila besar dua sudut dan panjang satu sisi diketahui

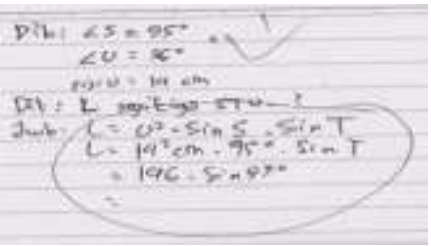

Dari gambar 8 terlihat bahwa siswa salah dalam menggunakan rumus mencari luas segitiga apabila besar dua sudut dan panjang satu sisi diketahui. Hal ini mengakibatkan siswa salah dalam menentukan luas segitiga STU.

2) Analisis Nilai Perkembangan Siswa

Persentase sumbangan nilai perkembangan siswa pada masing-masing siklus dapat dilihat dari tabel berikut.

Tabel 8. Nilai Perkembangan Siswa Pada Siklus I dan Siklus II

\begin{tabular}{|c|c|c|c|c|}
\hline $\begin{array}{c}\text { Nilai } \\
\text { Perkembangan } \\
\text { Siswa }\end{array}$ & \multicolumn{2}{|c|}{ Siklus I } & \multicolumn{2}{c|}{ Siklus II } \\
\cline { 2 - 5 } & Jumlah & Persentase(\%) & Jumlah & $\begin{array}{c}\text { Persentase } \\
(\%)\end{array}$ \\
\hline 5 & 9 & 28,13 & 1 & 3,13 \\
\hline 10 & 6 & 18,75 & 0 & 0 \\
\hline 20 & 1 & 3,13 & 2 & 6,25 \\
\hline 30 & 16 & 50 & 29 & 90,63 \\
\hline
\end{tabular}

Penghargaan masing-masing kelompok pada siklus I dan siklus II dapat dilihat dari tabel berikut.

Tabel 9. Penghargaan yang Diperoleh Masing-Masing Kelompok Pada Siklus I dan Siklus II

\begin{tabular}{|c|c|c|c|c|}
\hline \multirow{2}{*}{ Kelompok } & \multicolumn{2}{|c|}{ Siklus I } & \multicolumn{2}{c|}{ Siklus II } \\
\cline { 2 - 5 } & $\begin{array}{c}\text { Nilai } \\
\text { Perkembangan } \\
\text { Kelompok }\end{array}$ & $\begin{array}{c}\text { Kriteria } \\
\text { Penghargaan }\end{array}$ & $\begin{array}{c}\text { Nilai } \\
\text { Perkembangan } \\
\text { Kelompok }\end{array}$ & $\begin{array}{c}\text { Kriteria } \\
\text { Penghargaan }\end{array}$ \\
\hline I & 23,5 & Hebat & 23,75 & Hebat \\
\hline II & 18,75 & Hebat & 27,5 & Super \\
\hline III & 23,75 & Hebat & 30 & Super \\
\hline IV & 12,5 & Baik & 30 & Super \\
\hline V & 21,25 & Hebat & 30 & Super \\
\hline VI & 6,25 & Baik & 30 & Super \\
\hline VII & 20 & Hebat & 27,5 & Super \\
\hline VIII & 25 & Super & 30 & Super \\
\hline
\end{tabular}

Sumber : Lampiran $M_{2}$ 
Berdasarkan tabel 9 terlihat bahwa terjadi peningkatan penghargaan kelompok dari siklus I ke siklus II. Peningkatan ini mengakibatkan peningkatan nilai perkembangan yang disumbangkan masing-masing siswa untuk kelompok.

\section{3) Analisis Keberhasilan Tindakan}

Keberhasilan tindakan pada penelitian ini ditinjau dari peningkatan hasil belajar matematika siswa. Peningkatan hasil belajar dapat dilihat dari peningkatan skor hasil belajar matematika siswa sebelum tindakan dengan skor hasil belajar matematika siswa setelah diberi tindakan. Cara yang digunakan untuk melihat peningkatan hasil belajar adalah analisis distribusis frekuensi. Distribusi frekuensi skor dasar, skor ulangan harian I, dan skor ulangan harian II dapat dilihat pada tabel berikut

Tabel 10. Distribusi Frekuensi Skor Dasar, UH I, dan UH II

\begin{tabular}{|c|c|c|c|}
\hline $\begin{array}{c}\text { Distribusi } \\
\text { Interval }\end{array}$ & $\begin{array}{c}\text { Frekuensi } \\
\text { Skor Dasar }\end{array}$ & $\begin{array}{c}\text { Frekuensi } \\
\text { Ulangan Harian I }\end{array}$ & $\begin{array}{c}\text { Frekuensi Ulangan } \\
\text { Harian II }\end{array}$ \\
\hline $10-25$ & - & 5 & - \\
\hline $26-41$ & 2 & 4 & 2 \\
\hline $42-58$ & 6 & 3 & - \\
\hline $59-74$ & 18 & 5 & 2 \\
\hline $75-91$ & 6 & 10 & 6 \\
\hline $92-100$ & - & 5 & 22 \\
\hline
\end{tabular}

Sumber : Lampiran $H, L_{1}$, dan $L_{2}$

Berdasarkan tabel distribusi frekuensi di atas terlihat bahwa terjadi perubahan hasil belajar antara skor dasar, ulangan harian I dan ulangan harian II. Mengacu pada pendapat Suyanto, tindakan dikatakan berhasil apabila hasil belajar siswa setelah tindakan lebih baik dibanding sebelum tindakan maka tindakan dikatakan berhasil. Dengan demikian, dapat disimpulkan bahwa penerapan model pembelajaran kooperatif tipe Think Pair Square dapat meningkatkan hasil belajar siswa kelas $\mathrm{X}_{3}$ SMAN 5 Pekanbaru.

\section{Kesimpulan dan Saran}

Berdasarkan hasil penelitian dan pembahasan pada BAB IV, dapat disimpulkan bahwa penerapan pembelajaran kooperatif tipe Think Pair Square dapat meningkatkan hasil belajar matematika siswa kelas $\mathrm{X}_{3}$ SMAN 5 Pekanbaru pada materi pokok Trigonometri semester genap tahun pelajaran 2011/2012. 
49 | al-Khwarizmi, Volume III, Edisi 1, Maret 2015, Hal. 33 - 50.

Memperhatikan pembahasan dan kesimpulan di atas, maka peneliti mengajukan beberapa saran yang berhubungan dengan penerapan pembelajaran kooperatif TPS pada pembelajaran matematika, yaitu:

1. Penerapan pembelajaran kooperatif tipe Think Pair Square dapat dijadikan sebagai salah satu alternatif model pembelajaran yang dapat diterapkan untuk meningkatkan hasil belajar matematika siswa dalam proses pembelajaran di sekolah.

2. Agar penerapan pembelajaran kooperatif TPS dapat berlangsung dengan baik sesuai dengan perencanaan, maka pada saat fase think sebaiknya guru membiasakan siswa untuk bekerja secara mandiri. Guru harus mengupayakan agar siswa tidak bertanya langsung pada guru sebelum berusaha mengerjakan LKS sesuai dengan tahap-tahapnya.

\section{Daftar Pustaka}

Arikunto, S, Suhardjono, Supardi., 2009, Penelitian Tindakan Kelas, Bumi Aksara, Jakarta

B. Uno, Hamzah.2009.Model Pembelajaran :Menciptakan Proses Belajar Mengajar Yang Kreatif Dan Efektif. Bumi Aksara: Jakarta

BSNP (Badan Standar Nasional Pendidikan), 2006, Standar Isi KTSP, Jakarta.

Depdiknas., 2006, Kurikulum Tingkat Satuan Pendidikan, Pusat Kurikulum, Balitbang Depdiknas, Jakarta.

Djamarah, Bahri Syaiful dan Zain Aswan., 2006, Strategi Belajar

Mengajar, Rineka Cipta, Jakarta.

Dimyati dan Mudjiono, 2006, Belajar dan Pembelajaran, Rineka

Cipta, Jakarta.

Ibrahim, dkk.2000.Pembelajaran kooperatif.University Press:

Surabaya

Lie, A., 2008, Cooperative Learning, Gramedia, Jakarta.

Mulyasa, E., 2009, Implementasi Kurikulum Tingkat Satuan Pendidikan, Bumi Aksara, Jakarta.

Muslish, Masnur., 2009, Penelitian Tindakan Kelas itu Mudah, Bumi Aksara, Jakarta

Purwanto., 2009, Evaluasi Hasil Belajar, Pustaka Pelajar, Yogyakarta.

Ratumanan, T. G., 2002, Belajar dan Pembelajaran, UNESAUniversity Press, Surabaya 
Sagala., 2010, Konsep dan Makna Pembelajaran, Alfabeta, Bandung

Sardiman, A. M., 2007, Interaksi dan Motivasi Belajar Mengajar, PT. Raja Grafindo Persada. Jakarta.

Slameto., 2010, Belajar dan Faktor-Faktor yang Mempengaruhi, Rineka cipta: Jakarta.

Slavin, R.E., 1995, Cooperatif Learning Theori Research and Pratice, Allyin and Bacod Boston. , 2009, Cooperatif Learning Teori, Riset dan Praktik, Terjemahan Lita, Nusa Media, Jakarta.

Syah, Muhibbin., 2007, Psikologi Pendidikan dengan Pendekatan Baru, PT. Remaya Rosdarkarya, Bandung.

Sudjana, Nana., 2009, Dasar-Dasar Proses Mengajar, Sinar Baru Algesindo: Bandung. , 2009, Penilaian Hasil Proses Belajar

Mengajar.Remaja Rosda Karya:Bandung

Sugiyono., 2007, Metode Penelitian Kuantitatif, Kualitatif dan $R \&$ $D$, Alfabeta, Bandung.

Susilo.,2009, Penelitian Tindakan Kelas, Pustaka Book Publisher, Yogyakarta.

Sukarno.2009. Penelitian Tindakan Kelas. Surakarta: Media Perkasa

Suyanto., 1997, Pedoman Pelaksanaan Penelitian Tindakan Kelas, Dikti Depdikbud, Yogyakarta.

Trianto., 2009, Model-Model Pembelajaran Inovatif Beroriantasi Konstruktivistik, konsep, Landasan Teoritis-Praktis dan Implementasinya, Prestasi Pustaka, Jakarata. 